\title{
Coaching To Win: A Systematic Approach To Achieving Productivity Through Coaching
}

Joseph B. Mosca, Monmouth University, USA Alan Fazzari, Monmouth University, USA John Buzza, Monmouth University, USA

\begin{abstract}
The strategic business plan for any organization is very specific regarding sales force objectives and activities. Therefore, those responsible for the human capital of the sales function must be prepared to work directly with their sales employees, in an effort to meet management agreed upon goals, to gain market share, and to continuously improve overall performance. Over the years, the task of managing sales employees has been varied and undefined. Managing has been referred to as "the art of getting things done through people." For decades, experts have included planning, organizing, staffing, influencing or commanding, and controlling as the systematic way of making things happen. Recently, this commanding function has been dropped in preference to leading. It has been proven that coaching is more effective than the old approach of using fear and intimidation to achieve sales management objectives. This paper focuses on the need for these sales supervisors/managers to change their previously used tactics and embrace a new, proactive approach of "Coaching" their sales employees. This new approach is described in detail below and will help unlock the mysteries of becoming a viable and proactive sales supervisor. It will also give supervisors the tools needed to meet the needs of management and create a more productive, independent sales force. "Coaching" is becoming the leading preference for supervisors and managers, because it is proving to be more effective than previous used conventional methods. Coaching is the art of continually assessing and developing sales people, so they can be empowered to do their jobs well! Often, the conventional methods included command functioning tactics of fear and intimidation to motivate sales personnel. By using the "Coaching" approach, supervisors and managers have more control of their sales staff and of achieving their management goals. By developing a coaching relationship, which includes encouragement, listening, counseling, providing positive feedback, being supportive, resourcefulness, thinking with the future in mind, and modeling, these supervisors can give rise to a foundation where sales employees will be energized, aligned, and collectively mobilized to achieve and sustain customer satisfaction and trust. In so doing, sales employees will also be empowered to meet management's strategic goals.
\end{abstract}

\section{HUMAN CAPITAL}

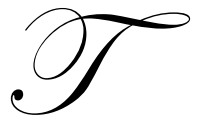

he Human Capital Theory suggested that education, training and development, and other knowledge had a positive impact on productivity and wages (Zula and Chermack, 2007) Becker (1993) noted three types of investments that have a direct relationship to the Rate of Return (ROR) on human capital: 1) On-the-job training, which included general and specific training from the organization and/or school, in conjunction with the direct production of goods and services. 2) Other knowledge, which included other information that a person obtained to increase their command of their economic situation outside the organization and 3 ) the training \& development that specialized in the production of training, which was different than the firms training and brought to the organization from places other than the organization. 
Sweetland (1996) reported that individuals and society as a whole could derive a huge economic benefit from investing in their employees. Traditionally, human resource practitioners and scholars were responsible for the Return On Investment (ROI) with regard to matters such as training their employees. Human resource departments commonly used two methods to monitor (ROI): 1) the Balanced Scorecard (BSC) approach (Kaplan \& Norton, 1992), and 2) the Human Resource Scorecard (HRSC), as posited by Becker, Huselid \& Ulrich (2001). Both of these measurement systems focused on how an organization utilized their resources to create a chain of value that ultimately drove favorable customer satisfaction, which in turn fueled an overall positive performance.

Managers must fully understand how value is created within an organization in order to incorporate a successful business strategy within their departments. Management should attend to more than just their financials, because it ultimately affects the outcome of their strategic implementation and long term goals (Becker, Huselid \& Ulrich, 2001). In order to truly understand and utilize the logic of "value-creation", management must focus on variables such as performance drivers, for example: customer loyalty is a key source of competitive advantage. Sales managers must begin to understand and appreciate the precursors to financial success. By so doing, they will incorporate the "cause \& effect logic" into the framework of their goals and objectives. Too many sales and marketing managers continue to make day-to-day tactical decisions, without paying enough attention to their strategic direction. Often these managers know how to increase profits over last quarter, but they do not analyze or chart the course that has taken them there (Gebhart, 2006).

Thacker and Handscombe (2003) reported that managers, who interacted with their employees, had a much larger impact on the outcome of their production and ultimately showed to be a key component to an organization's profitable growth. This outcome could be very profitable, but if done incorrectly, it could also be constraining to the process. Therefore, it is imperative that the process be evaluated properly. West \& Anderson (1996) discussed the importance of the team's characteristics and Burpit \& Bigoness (1997) noted that the role of team empowerment had a direct correlation to an organization's profitability and growth. Tovstiga \& Tulugurova (2007) report that within resource-based and knowledge based organizations, in order to increase competitive advantage the organization should mobilize its intangible assets in the form of knowledge, technological skills and experience, and strategic capabilities. Knowledge in the form of competencies, capabilities, experience, and relationships, significantly differentiated one enterprises success from another (Birchall \& Tovstiga, 2001). In the area of sales, it has been proven that some of those competencies were the direct result of a sales manager exerting his/her trained ability to listen instead of criticize and to advise rather than direct (Kornik, 2007).

\section{SALESMANSHIP}

Salesmanship is completely different now (Gray, 2008). At one time, salesmen greeted, qualified, presented, demonstrated, overcame objection, closed, and possibly followed-up with the needs of their customers. But times have changed and there is a new managerial approach, which has proven to be more effective than previously used methods. A new "coaching approach" would involve treating people like human beings while also dealing with their lifestyle needs and preferences. Buchanan (2009) noted that today's sales people often spend too much time reciting and preparing arguments, when they should have spent their time more productively evaluating their customer's needs and concerns. These bad habits persist, in part, because many business school professors have neglected to teach their students the basic fundamentals of sales.

The art of sales is not a random process with a "pitch" as it may have been described years ago. The art of selling is a process which is taught, learned, and utilized in the field. Therefore, individual sales people and those directly involved in the sales management process today should be appreciated and respected.

In addition to the art of salesmanship changing, those individuals currently entering this field are also different. The present generational differences have become one of the thorniest issues in the workplace (Gebhart, 2006). For that reason, one size no longer fits all. New data has identified these changes and also identified the need to change the style of management by which students are taught and how salespeople manage their employees. Keough (2007) reported that many years ago, most sales managers motivated their salespeople with fear and intimidation. Today is a new selling environment and the old management style has been proven to be less effective than the new coaching style. 
Motivating salespeople for the long run takes time, effort, and a personalized approach. The majority of salespeople do not work well independently and need ongoing encouragement and advice to continue being productive. Building each salesperson's self-esteem is critical to realizing the objectives of their sales manager and ultimately the success of reaching management's expectations and agreed upon goals. Rigby (2008) agreed and added that most salespeople typically feel isolated. Being "out of sight" should not mean "out of mind." There are some salespeople who like working alone for short periods of time; but they beat to their own drummer, and at times, do not play by the rules (Barlow, 2007).

Selling is difficult work and the rejections salespeople continuously face is discouraging (Tracy, 2008). This is all the more reason why coaching and counseling is the most effective method of motivating a sales force (Kornik, 2007). The best salespeople today are warm, friendly, personable, and completely focused on the customers. They need to gain the trust of their customers and, while doing so, make recommendations instead of strong-armed sales closings.

\section{SALES MANAGEMENT}

The traditional role of a manager (boss) has been redefined or even eliminated (Sims, 1994). The term "boss" was part of the past that dragged with Neanderthal baggage, brutish images of people being ordered around, chewed out, or employees being labeled as subordinates (Kiechel, 1991). Kiechel also noted that the term "leader", back in the eighties, had an even bigger impact, because the term implied a manager who had "visionary" and "transformational abilities". More importantly, when the term is taken literally, it implies that employees are followers.

William Bottom, a Washington University professor, insightfully termed this newly recognized management style as "coaching" and stated, "We need to function more as coaches and less as dictators. A sales manager's job is changing and their skill requirements are changing as well." Management has been called the "art of getting things done through people"(Stoner \& Wankel, p.3-4,1986). Managers achieve their organizational goals by arranging and assisting others to perform whatever tasks deemed necessary - not necessarily by performing the tasks themselves. Over the years, those activities included planning, organizing, staffing, influencing, leading, and controlling (Haimann, Scott, \& Connor, 1985; Szilagyi, 1984; Williams, 2008).

\section{Figure 1: Historical Management was Getting Work Done through People}

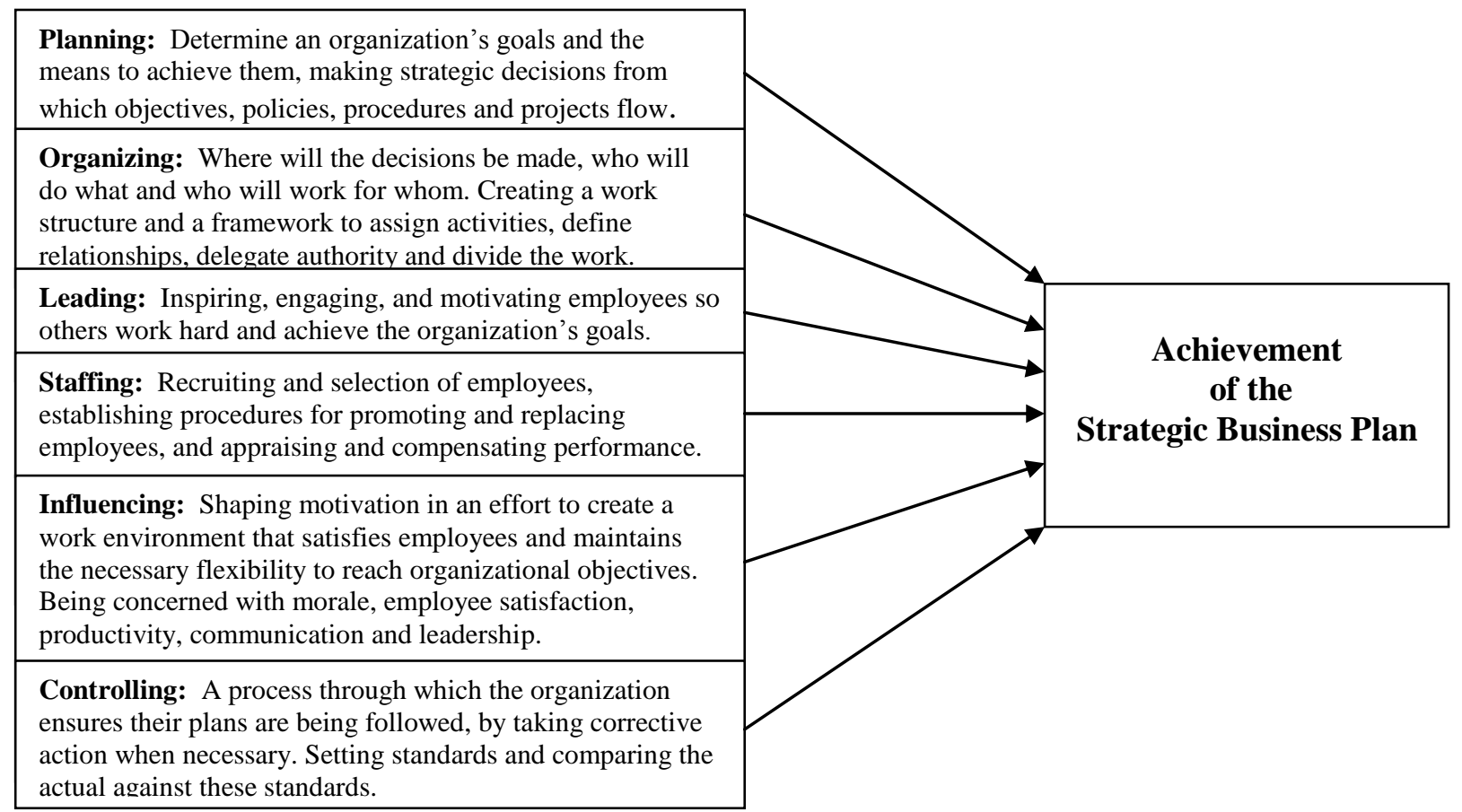


As you can see in Figure 1, historically management was getting work done through people. There were six basic activities managers did to achieve their goals: planning, organizing, leading, staffing, influencing, and controlling. Even the term leading was used to inspire and motivate employees to work harder. However, there was never any mention of development, assessment, counseling, or mentoring; the four basic, yet critical roles of a coach. Figure 2 depicts these and other roles of a manager by adding coaching as a primary value added process to the model of sales management.

Figure 2: Adding Coaching as a Primary Value Also Added Process to the Model of Managing

Coaching: Possessing a prospective focus while developing employees through personalized, formal and informal instruction, empowering, positively reinforcing acceptable work, providing consistent feedback, gathering information, listening, acting as a role model, creating the proper work culture, sharing coping skills, guiding, building confidence, supporting, stress management, elimination of maladaptive behaviors, tapping greater potential, focusing on emotional aspects and feeling of employee and performance, character and relationship building, counseling and mentoring.

Professor J. Du Brin, at Rochester Institute of Technology, stated: "People have more respect for a coach than they do for any other authority figure, perhaps because athletes are so prevalent in our culture." Good management is working through others in an effort to accomplish the tasks that help an organization fulfill its objectives as efficiently as possible (Williams 2008). Over the past decade, managers lost their legitimacy in the face of a wide breakdown of trust and self-policing (Khurana \& Nohria, 2008). As customers continue to demand more quality and clear value for their money (Simms, 2005), the interaction between the customer and the sales employee representing the organization needs to set the stage for ongoing and continuous customer satisfaction (Wangenheim, Evanshitzky \& Wunderrich, 2007).

Within the function known as sales, a successful sales manager must now also have a broad based strategy and commitment to a lifetime of learning (Buchanan, 2009). This strategy must consist of at least one or more of the following actions in order to be effective: 1) setting the sales force objectives, 2) structuring the sales organization and territories, 3) determining the size and type of resources needed, 4) creating the proper compensation plan, 5) selecting and training, 6) developing, coaching and mentoring, 7) supervising, and 8) evaluating their sales employees. Selling is more than order taking and salespeople must focus on their customer's orientation and satisfaction. The sales manager of the future must be prepared to assist his or her sales team to master the selling process in a different manner than once was acceptable.

Organizations are very detailed about their sales force objectives and subsequent activities. Therefore, a sales manager must be prepared to consider adjusting his or her style and attitude toward the human capital in sales as well. One manner in which to accomplish this task is to integrate mentoring and coaching into their management toolkits, while working directly with their sales force to meet the organization's overall business plan. In short, a sales manager's approach must be modified in order to create a productive and efficient sales team.

In an effort to meet their business objectives, organizations are restructuring themselves and changing their work methods and marketing approach. Organizations realize that the results of their sales people, while selling and working with customers, ultimately has a direct correlation to obtaining their strategic business goals and the effectiveness and solvency of the entire company. Yet, according to research completed by PR Newswire (2008), only one half of all salespeople have a solid understanding of their organization's strategy and sales managers often lack the leadership skills needed to succeed. Organizations continue to focus mostly on the development of sales manager's tactical skills. Forum Corporation found that 70 percent of managers can dramatically increase their effectiveness by focusing on strategy, coaching, and motivation. (Wickman, 2008)

Sales managers need to be able to communicate their organization's sales strategy in a way that makes sense, so sales employees can align themselves properly. With coaching and individualized motivation techniques, managers can easily become "thinking partners" within their sales teams. For example, if a sales manager needs to compete regionally, divisionally, and locally with a de-centralized sales force, although the product or service being offered might be the same, the sales manager will have to build a sales team that vary according to skills, 
knowledge, and abilities - specifically for the various geographical areas being covered. This will require a great deal of counseling and effective team building on the part of the sales manager. In this particular case, while working with sales professionals as in so many other cases, one size will not fit all.

Research has shown that those responsible for sales employees should take on a more active role of coach and mentor, rather than that of a manager or boss. Sales managers tend to be driven by traditionally narrow financial results. This coaching approach has proven to be more effective than traditional styles, while meeting diversely different demands. Kuster \& Canales (2008) reported that results should not only be limited to statistical analysis reports or comparison with objectives; sales management must also value the acquisition of information, the scope of sales force effectiveness, and the effectiveness of the control system in place. Today, the most effective sales team has a manager that is more of a coach and a counselor, who watches sales professionals interact, and provides positive feedback in an effort to motivate and improve their performance. (Kornik, 2007)

The age of "bigger is better" is over, and now the size of an organization has to coincide with the strategic plans for the future (Drucker, 1989). Due to the recent economic challenges, organizations are being forced to reduce the amount of resources originally available. This could mean that sales managers may have limited funding and have to adjust to a smaller sales team, while performing the same projected goals. Both sales employees and managers will then need to be more flexible with changes of roles and responsibilities. This also suggests that sales managers need to be cognizant of the size of their sales force, while maintaining their effectiveness and productivity. Sales employees need to maintain management roles to insure their employment security within that same organization.

Sustainable business growth does not come from managerial strategies such as cutting costs through layoffs, using contract employees, salary and promotion freezes or even from the reduction in training and development (Ahlrichs, 2000). Companies that have grown to be successful are the ones that continue to place the needs of their employees first and develop their people (Kanter, 1983) while including them in critical decision and problem solving (Marshall, 1995). During these changing and challenging managerial, economic, and employee cycles, it is crucial that sales employees feel fulfilled and satisfied with his or her position. This will have a direct relationship to the organization's overall success. This necessity of job satisfaction may have momentarily been forgotten by management and needs to be re-evaluated.

Research has shown that relations-oriented and development-oriented behaviors of leaders are positively related to job satisfaction (Fernandez, 2008), which will then lead to increased performance. Organizations cannot forget the critical importance of being sensitive to the needs of employees. In the area of sales management, incorporating the importance of this practice into a coaching style will almost assuredly become a requirement for the future. Sales managers will need to be sensitized to the participative employee, the changing social tendencies, and the decentralized organization (Brechner, 1991). The question then becomes, "have organizations already begun to move in this direction regarding their sales culture?" James Champy (1995) noted that managers have radically changed by engaging in the Emersonian thinking, which included questioning everything. Michael Hammer (1995), a colleague of Champy, advocated that the future manager must play the role of the coach/teacher and take an active part in this development of employees in order to be proactive, accepted, and successful (Lancaster, 1995).

\section{ORGANIZATIONAL CHANGES REQUIRE A NEW SALES MANAGEMENT STYLE}

The concept of a changing management style is not a new one. It was posited by Limerick and Cunnington in 1989. They identified three eras through which management has passed: (1) the Classical, Traditional Model, (2) the Human Relations Model, and (3) the Systems Model. In all three of these management styles, sales management technology depended mostly upon a mature and proactive sales individual to fulfill the needs of their customers, while concerning themselves with the integration of strategy, structure, and culture. The sales managers of the future will have to assist with the development of their sales force employees and should strive to be role models for their salespeople by proactively setting a positive example through their own behavior (Rich 1997). In this global economy, where markets are forever changing, a sales force will have to be capable of adjusting for behavioral, procedural, and structural changes. This can be accomplished through the proper training of sales managers and by equipping them with the needed skills for sales force development. 
In the past companies would generally send their new salespeople into the field almost immediately after an organizational orientation usually facilitated by human resources. They were provided with samples and a sales book, given general instructions, and possibly a few days training on product knowledge. For many companies, ongoing formalized sales training was and still may be too expensive. Presently, there are a variety of methods by which organizations can and will improve the sales skills of an organization's human capital; formal education opportunities, on-the-job training, and firm-provided training (Machin \& Vignoles, 2004). As noted previously, business schools that typically teach the core principles of being a successful business person do not have courses on the fundamental skills needed for today's sales management. This would then leave an organization that is serious about investing in its sales human capital to create sustained firm-provided training along with enhancing its on-thejob training process to also contain a broader based curriculum beyond the technical product knowledge and sales skills commonly taught.

Today's sales people have a unique blend of strengths and aptitudes (Kahle, 2008). Exceptional salespeople often have very high standards for themselves and thus for everyone else around them. However, they are often so highly focused on their customers' needs, that it becomes a detriment to their relationships with their colleagues. On the other hand, new sales managers must have a similar understanding of their customer relationship, while being able to motivate their sales employees to peak performance (Evenson, 2005). Managers must also make numerous decisions in order to succeed in capturing and growing market share (Bates, 2007). These may include strategic or tactical decisions, along with being aware of the complex linkages both internal and external to the organization. Sales managers must now possess a different viewpoint and vision. Their training and development should be ongoing, contain a curriculum which focuses upon motivating others and making them feel valued as workers along with line of site thinking toward the future, coaching, and counseling.

\section{THE NEED FOR A SALES MANAGEMENT TRAINING UP-DATE}

Training specialists agree that new ideas have to be disseminated with care. Managerial skills, changes in work methods, organizational goals, and attitudes must all be transferred from the training classroom back into the workforce. The suggestion here is that the training and development of sales managers must not remain only with those attending the session, but should also be transferred to their individual sales force. Huczynski (1989) emphasized that during all training sessions, it is not only important for the facilitator to become familiar with all members of the organization, but also to become cognizant of what required behavioral changes are needed. For example, if the sales force is decentralized, the trainer needs to understand how the new methods, goals, or attitudes are going to be transferred from the management level to the sales level. The trainer must also be aware of all the types of relationships on which the trainees will have to manage their employees in order to effectively implement the proposed changes. This is an indication that trainers can achieve their goals by designing the course content in terms of sales force composition, sales expectations, and predicted organizational outcomes. The basis for this is explained through Huczynski (1989) who places a great deal of emphasis on the manner in which the trainees conceptualize the changes.

Training should include three basic expected change components: behavioral, procedural, and structural change concepts. From a sales manager's perspective, the focus should be to improve upon skills relating to sales force development, sales performance, and coaching. These are required behavioral changes. Trainees must also be introduced to procedural changes regarding organizational processes. Finally, to implement structural changes within an organization, all trainees must have a better perception of their individual role in the organization. They must also understand what role others play in the organization, and what their inter-relationships will be (Huczynski, 1989).

\section{COACHING: A METHOD OF SALESFORCE DEVELOPMENT}

Coaching draws on a rich heritage of individual and organizational changes practiced in the fields of organizational behavior, psychology, and psychotherapy (Oren, Binkert \& Clancy, 2007). Major shifts have occurred in the field of coaching, from a deficit based structure to one of well-being, and attention to the positive basis of change. According to Coutu and Kauffman (2009), ten years ago most organizations engaged a coach who attempted to fix the toxic behavior of employees and management without taking any real active role in their development. Today, however, most coaching is about developing the capabilities of high-potential performers. 
The origins of the word "coaching" comes from the Hungarian village of Kocs and the more comfortable covered wheeled wagon or carriage (koczi). It was first developed to carry its passengers through the harsh terrain, protecting from the elements on their way from one point to another (Hendrickson, 1987). This term has been modified to reflect a coaching of employees.

Conventional coaching tends to be specific in that the coach him/herself specializes in one profession or a single expertise (Martin, 2005). Specialty coaches were originally hired in the guise of management consultants to help an organization, when profits were going downward. They were usually retained on a temporary basis, after an organization identified some missing skills, needed re-engineering or had to address barriers or conflicts between layers within their structure. As a profession, there are a variety of models of coaching; co-active coaching (Whitworth, Kimsey-House \& Sandahl, 1998), life coaching (Sholten, 2003; Martin, 2005), appreciative coaching (Oren et.al. 2007), executive coaching, performance coaching (Stern, 2004), and mentoring (McCauley, 2007). The last two constructs, performance coaching and mentoring, should be used when focusing on changing the working strategies of a sales force.

Performance coaching focuses on an employee's specific performance potential, job requirements, deficiencies or de-railers and on how to fill performance gaps to shape one's performance (Stern, 2004). Miller (1926) reviewed Coleman Griffith's paper, "The Psychology of Coaching", and he concluded that coaching should be approached by looking at three levels of development; (1) Habit - formation and interference, distribution of learning periods, and effective presentation of material, (2) Natural Causes - corrective measures, personality, and will power, and lastly (3) Leadership - teacher, pal, friend, and a builder of character. Peterson and Millier (2005) noted that coaching is guided by two overarching principles; (1) to be the kind of coach that you would like to work with. Since everyone is different, don't follow the same routine process with everyone and (2) aim to be a great coach and not just a good one. One can accomplish this by asking themselves "what is the most positive and powerful thing I can do right now with my employee?"

When performed correctly, coaching is an effective way of improving business results (Hall, Otazo, \& Hollenbeck, 1999). Research has shown that coaching (which included goal setting, problem solving, practice, feedback, supervisory involvement, evaluation of end results, and public presentation) will increase productivity fourfold over training alone (Olivero, Bane, \& Kopelman 1997). Coaching has become a way to ensure that the knowledge acquired during training actually emerges as skills that are applied on the job. It has also shown to produce greater work satisfaction and a tendency toward greater life satisfaction (Bowles \& Picano, 2006).

Despite the positive outlook toward coaching and the widespread use of the technique for behavior change, coaches are often challenged by the cynicism of business leaders who fundamentally believe that people, like tigers, never change their stripes (Wasylyshyn, Gronsky \& Haas, 2006). It is argued, however, that meaningful changes seldom happen in a one-shot intervention, and so an ongoing intervention process is potentially more thorough and long lasting (Tobias, 1996). Coaching should be individually tailored and focused on the current issue or problem at hand, as opposed to a "one-size-fits-all" menu provided in many seminars. Coaching also needs to be continually focused and changes made relevant to that individual problem. If coaching is done correctly, sales management can create a satisfied, productive, and knowledge- able sales team by developing activities which are at the core of a coaching venue. Even the top players and producers need coaching to shine even brighter (Barker, 2005).

Traditionally, managing sales employees has been done in a fairly harsh, macho culture. Today however, coaching has been proven to be the model of choice with regard to sales employee management (Mathews (2004). Unfortunately, there has been a tendency for sales managers to appear to be coaching, when in reality they use tools such as targets, numbers, pipeline, opportunities, and closings on the horizon, to forecast the mantra of many sales meetings. A more effective sales manager will utilize coaching as a tool. This motivates and improves the interaction between his employees on an emotional basis which is just as critical.

Salesmanship is one of the most measurable professions and it is nearly impossible to hide poor performance. Effective coaches realize this, but they also understand that by breaking down the whole into subprocesses (confidence, emotions, trends, approach and overall interrelationship abilities) they can identify where the gaps are and focus on the inputs that flow and result in the output. Sanchez (1998) outlined four tips to being a 
better sales coach: (1) don't wait for a crisis, (2) get the sales person's perspective, (3) make improvements in manageable steps, and (4) be positive. These tips are based upon the simple notion that people want to perform well, but are not always sure on how to do that. As a coach, your job is to point out the "how" very precisely, have faith, trust them and help them make the necessary adjustments needed to be successful.

Coaching is not therapy where the focus is often on an interpersonal health challenge or an identifiable health issue that interferes with a client's level of life functioning. Therapy is retrospective, dealing with issues and repairing damage of a past. Coaching's orientation is prospective, focusing on goals, untapped potential, and critical success factors in someone who seeks to maximize his or her fulfillment in life and work (Hart, Blattner, \& Leipsic (2001). Developing and coaching a sales force is an ongoing process of identifying the competencies needed and evaluating the competencies your sales force possesses. Then you close the gap between the two. It has been proven that employee development programs can strongly influence career growth and job performance. The proposed method to achieve this goal is to employ a coaching strategy for sales force development (Shore \& Bloom, 1986). Coaching is one of the roles sales managers should include in their future annual strategic goals.

Currently, organizations have had to downsize, re-engineer, restructure, right-size, and flatten their sales force, leaving them with less help and more work. The present nation-wide recession has created even more belt tightening in all functions. The sales managers of the future need to be better at team building and empowering their sales people to work more effectively, in an effort to maintain their productivity and be more cost effective with fewer resources. Therefore, those responsible for sales must modify their management approach toward a more coaching venue while also creating a definite strategic plan.

Some strategists note that there is a hot new trend that will shape corporate America for years to come (Wiesendanger, 1995). She noted that first came time and motion, then the trend became reengineering with quality management and now it is "Business Psychology." It appears that with all of these management models, the sales manager of the future might well learn a thing or two from a good coach in order to develop an efficient and effective sales team. Sales managers should also consider viewing issues from a human resource point of view, and prepare themselves to counsell and coach members of their sales force. According to Lukaszewski (1988), the human resource perspective is one where the organization develops managers to be complete thinkers. The complete thinker is like a counselor /coach, who identifies the challenges present, but also helps by offering options and solutions taking into account the needs of the entire organization. A complete thinker is trained to exhibit at least five attributes; the ability to identify, describe and interpret, forecast outcomes, recommend, and test specific ideas regardless of the situation. Coaching sales people can help develop the "complete thinker" mentality.

\section{HOW TO EFFECTIVELY COACH YOUR SALESFORCE}

Sales' coaching encompasses a variety of "learned people skills", which include setting clear boundaries, letting your sales people know you really mean what you say, managing the critics of your sales team, while embracing a sales person's passion and not mistaking a creative sales approach for inappropriate behavior (Barlow 2007). Kombarakaran, Yang, Baker, \& Fernandes (2008) noted five areas of change that resulted from those who prescribe to a model of coaching. They: 1) managed people more effectively, 2) created better relationships with managers, 3) there was improved goal setting and prioritization, 4) increased engagement and productivity, and 5) more effective dialogue and communication. To that end, results of effective coaching will lead to the development of sound selling skills and good selling habits (Knippen \& Green, 1990), increased performance, job satisfaction and decreased attrition (Anonymous, 2009), and higher levels of impact, confidence and influence (Peitler, 2009).

During the process of coaching, a coach allows the sales representative to practice first, while providing specific, consistent feedback, counseling, and modeling in an effort to continuously improve. For example, a sport team will engage in numerous pre-season training sessions with a variety of specialized coaches. What would happen if there was little or no follow-up or even the presence of any of the coaches once the season begins? Who would provide invaluable and consistent personalized and group feedback? Unfortunately, this happens often with newly hired sales representatives. The initial classroom training ends and then the sales representative is placed in the field with minimum oversight, while being expected to perform and reach a goal set prior to him/her joining the organization. Salesmanship can be taught, scaled, and replicated (Buchanan, 2009), but in order to manage an allstar sales team much more than the classroom training is needed (Evensen, 2005). 
Sales representatives, as noted above, can be compared to athletes, each having their own individual strengths and weaknesses. A sales manager's job can also be likened to that of a sports coach. Both need to be concerned with a learning curve and ultimate performance of those they are responsible for in order to be effective. They must provide guidance, counseling, advice, and opportunities for improvement while also taking on multiple roles as teacher, motivator, strategist, organizer, and character builder, (Feltz, Chase, Moritz, \& Sullivan, 1999). In order for this process to be successful, sales managers must understand the boundaries that separate coaching from other forms of intervention, specifically what a coach is, and what a coach is not. The role of the coach is not to be a therapist (Hart, Blattner \& Liipsic, 2001), although there is an overlap at times. Coaching and therapy are both based in similar theoretical constructs, and similar practitioner-client issues may arise. Coaching is not cheerleading, although motivation is a vital part of the process. Cheerleading is typically a focus for a specific point in time to energize a group. Coaching is an ongoing process which distinguishes itself from the seminar and workshop oneshot motivational approach (Tobias, 1996).

Coaching is a repetitive consistent process of observing, providing feedback, counseling, taking corrective actions, and collaboratively making specific plans. One of the most important steps in effective coaching is creating the foundation and type of relationship where an employee feels comfortable about "needing to know" something. Once a salesperson is not embarrassed or afraid to ask questions beyond product costs, margins, product performance, etc., then a breakthrough occurs and the coaching relationship truly begins. At this stage, the coach can now frame their specific learning goals and describe simple, step- by- step process of how successful selling is accomplished based on what has been observed and close the gap between the two. As their coach, the sales manager can discuss the next steps and actually demonstrate the process.

Coaches do not step aside to observe, counsel, or guide from a distance (Franco, 1995). They are continually interacting with the sales person, trying to restructure their cognitive thoughts and behavior patterns. They are also continually suggesting new ways to obtain the desired behavioral changes to avoid repeating errors in the future (Ducharme, 2004).

\section{DEFINING THE SALES COACHING COMPONENTS}

The role of the sales coach is one who assists sales representatives to grow and improve their selling competence. This can only be accomplished if the coach has engaged on a day-to-day basis. Coaches are the individuals who set sales representative's goals and listed below are the components required for coaching to theses goals.

\section{Clarifying expected performance}

This component is part of the selling competence cycle and begins with the identification of important aspects relating to the sales representative's responsibilities. At this stage, it becomes critical to clarify the expected performance levels for servicing accounts and related tasks. Use of a written job description, at this point, becomes helpful for analysis and clarification of standards established by the firm. The job description not only describes important aspects of the servicing of accounts, but includes what needs to be done.

Selling is often individual in style, but also must incorporate what a particular organization requires and expects from its representatives. A good (sales manager), coach, would use standards that have been established and accepted by both coach and sales representative. All of the mentioned processes are part of a good evaluation of selling performance. This would be especially important when seasoned sales representatives are hired, and need to be trained to comply with organizational standards.

\section{Evaluating sales performance}

In order to measure the adequacy of the sales representative's competence, sales performance must objectively be evaluated. This is accomplished by comparing actual performance to previously agreed upon goals. Note that the coach and the sales representative establish these standards and then reach an agreement as to how the task will be accomplished. Selling competence is individualistic by nature. Therefore each individual has to be a part of establishing their goals in order to comply with organizational and customer needs. 
Unlike traditional methods of the past, where subjective impressions or comparison of one sales representative with another were used for the evaluation during quarterly and annual performance appraisals, coaching is much different. The sales representative is less defensive during the evaluation process, because they will have the opportunity to collaborate with their coach as they rate performance. In addition, the coach and the sales representatives can evaluate the 'value chains.' These chains identify the primary and supporting activities used by the sales person to create value for their customers (Huff, Floyed, Sherman, Terjesen, 2009).

A good sales coach would minimize the authoritarian character of the evaluation interview by allowing for participation as equals. Both parties need to be prepared for the interview by pre-determining concerns and issues at hand. This encourages sales representatives to engage in conversation, which minimizes threats to their self-esteem. Also, traditional evaluations would often only focus on one important performance change that contributed to their success. A new coaching approach recommends positive changes to a sales representative rather than directing them. This would create a better, long term working relationship, while keeping in mind that the art of selling is individualized and achievements are also individual. According to Forray (1995), employees that have high quality, trusting relationships with their managers perform better and ultimately receive higher performance evaluations. On the other hand, those employees without quality relationships with their managers are not evaluated as highly and seem to be at a lower scale of performance overall (Forray, 1995). This may be the result of the manager feeling a positive influence was not present in their relationship.

\section{Planning for sales performance}

Planning for sales performance is the explaining of specific actions that the sales representative will take based upon the results of the specific areas chosen from the appraisal. This should take place during a counseling session. The coach and sales representative mutually design the plan. Good coaches usually assist with a practicable plan to develop specific skills and knowledge. The plan should include a reasonable deadline and describe the deliverable. Being that collaboration helps to build commitment, it's important for both the coach and sales representative to discuss what the commitment is, how will it be accomplished, and when.

\section{THE COACH'S ROLE}

The coach's primary role is to empower, guide, counsel, and mentor his/her sales representatives to reach desired performance levels. The coach helps the employee implement performance plans by providing praise and constant counseling along with constructive criticism when applicable. In order to keep sales representatives along the path to better performance, coaching should be frequent, consistent and focused. This includes at the minimum constant gathering of information on sales force competence, the willingness to discuss areas of improve-ment, helping with corrective actions to be taken, and constantly reviewing the sales representative's plan for implementation (Shore \& Bloom, 1986). The coach's main objective is always being there when needed, spoting areas needing improvement, encouraging, and motivating. Coaching becomes even more critical when the sales representative has had a bad day, or did not close the sale.

\section{COACHING AS A SALES MANAGEMENT TOOL}

We have already established that Coaching is a collaborative tool that goes far beyond the typical performance appraisal evaluations and is much more effective than conventional tools previously used. Let us refer to a management basic: Getting things done through other people is an elementary management principle past down through the decades. All organizations need people and therefore, all organizations need managers to meet their organization's goals and objectives.

What will make a manager successful? All managers are evaluated on how well their employees perform; therefore, a good sales manager would then want to focus on helping their sales force succeed. The most significant contribution a sales manager can make to an organization is to develop a sales force to perform effectively and efficiently. Sales force development will require an understanding of what motivates them. Behavioral scientists have found three determinants that motivate an employee to seek job satisfaction. 


\section{DEFINING THE MOTIVATORS}

According to Allenbaugh (1983), employees need to experience three core job motivators. As job satisfiers, these three core job factors rated higher than wages and benefits. A coach needs to understand each employee's values and integrate them into the job design. Allenbaugh (1983) defined these motivators as: (1) Meaningfulness; employees must feel that their work is worthwhile and important as perceived by their standards, (2) Responsibility; employees must feel a sense of accountability for job outcome, and (3) Results; employees must be able to determine what is performed well, what needs improvement, and what the targeted goals are?

Why is continuous coaching better than a one shot performance appraisal? Traditionally, companies often conducted employee performance appraisals, at least once annually. Research revealed that performance appraisals conducted annually are a poor measure of an employee's competence and tends to focus only on the employees weaknesses. Since coaching is an ongoing process of feedback, it tends to influence behavior to increase job knowledge and improve productivity. Ongoing feedback emphasizes the employee's strengths and weaknesses, but it also creates a balance whereby the individual views this interaction as positive counseling.

Coaching becomes a valuable tool in sales management, because it allows the sales representative to identify outcomes valued by their organization. This in itself serves as a positive motivator, leading to increased sales competence and performance. Coaching leads to increased knowledge of employees, more understanding of their jobs, and more positive relationships. When sales representatives take part in determining their goals and how they are to be reached, the results are likely to be positive. By combining the coaching components with the motivators noted above if used properly these tools can assist the coach in achieving sales force growth.

According to Lucas (1994), coaches must hone their ability to receive and provide feedback. The following are Lucas's six elements for coaching employees to success:

1) Stating what you observe: Avoid argumentation and provide specific examples of observed performance, this will be considered as a fair observation by the employee.

2) Describe your feelings about performance: Reduce defensiveness by also providing personal feedback on how the employee can focus attention on incorrect performance.

3) Explain the impact of the performance: Remind employees of the impact their actions have on the organization and their own performance.

4) Solicit understanding and agreement of their commitment: Discuss the employee's understanding of why successful completion is important and what can you and the employee do together to attain improvement.

5) Make suggestions for improvement, if necessary: Provide suggestions or demonstrate the task so the employee understands procedures. The role of the coach is not to give the answers, but to offer tools and counseling.

6) Reinforce: Reassure the employee that you are available at all times for support and counseling.

\section{EFFECTIVE COACHING}

Gary Bielous (1994) reported that no amount of leadership can replace the need for managers to develop their employees. This suggests that if sales managers implement a new coaching style correctly, it would positively affect their sales force performance. This new approach would also give sales employees a sense of confidence and accomplishment, as they meet their organization's strategic goals. Coincidentally, while the sales employees are effectively producing and meeting their goals, their manager's are doing the same through the coaching venue.

Successful organizations are beginning to realize that the traditional role of leader supremacy is out-dated and ultimately ineffective. In its place, new leader-employee partnerships are being formed and as these same leaders take the role of coach rather than bosses, these partnerships are beginning to produce enthusiasm and commitment on the part of employees, resulting in huge productivity gains. 
This new concept allows a sales manager the opportunity to take an active role in realizing their sales employees achievements and ultimately achieving their own goals, by knowing their employees, both their strengths, and weaknesses. Coaching for effectiveness would then be accomplished by employing the following: know the subject to be discussed, be sure the message intended is clearly understood, instill trust in the employee by displaying patients, and be sure to follow-up (Bielous, 1994).

\section{COACHING AND LEADERSHIP DIFFERENCES}

James McGregor Burns (1978) describes leadership as "one of the most observed and least understood phenomena on earth." Leadership research remains ambiguous, because it has been narrowly focused upon and does not usually integrate the findings from various approaches. One of the major exceptions to this criticism is the current research on transformational and transactional leadership. The reason for this criticism is that a majority of the research on transformational and transactional leadership focuses primarily on the overall process of leadership (Burns, 1978).

Transactional leadership focuses on clarifying employees' role and task requirements along with providing the necessary positive and negative rewards contingent on performance Kritner \& Kinicki (2008). This leadership style also encompasses the fundamental managerial activities noted previously; setting goals, monitoring progress and rewarding or punishing employees for their level of goal accomplishment. On the other hand, the transformational approach engenders trust, seeks to develop leadership in employees, exhibits self-sacrifice and becomes the moral agent where followers focus on objectives so that the immediate needs of the group are met. This leadership style often produces organizational change and visible results because it fosters a high level of intrinsic motivation, trust, commitment and loyalty from employees. According to Bass (1990), transactional leadership is a prescription for mediocrity. Bass identifies transformational leadership as occurring when leaders broaden and elevate the interests of their employees. The leader needs to generate awareness and acceptance of the employee's mission while instilling upon them to look beyond their own self-interests for the good of the group. This form of leadership seems to be charismatic that could lead the employees becoming followers (Bass, 1990).

The bottom line for sales managers is to attain optimal effectiveness, increase sales, and remain competitive, all at the same time. The sales managers of the future can now achieve this competitive advantage by altering their perception concerning their sales force and through their employee relationship. According to Pfeffer (1995), this means that a manager's success can be achieved by working directly with their employees and not replacing them or limiting the scope of their activities. He also infers that the workforce should be viewed as strategic advantage resource and not as a cost to be avoided.

Therefore, it is highly recommended that all sales managers include this new coaching approach to their leadership style. Although there is no single management style that will produce all the results needed, the authors are recommending that a coaching approach included in the toolkit of sales leaders and provide the flexibility to fit any and all needs as they arise.

\section{CONCLUSION}

Human nature dictates that we will always resist change. Our approach to productivity, however, is quite the opposite in that we become very proactive in trying to find different and creative ways to spur growth. This dichotomy is quite prevalent in the managing of employees. The question becomes "While we talk the talk, do we truly walk the walk?" Our paper is very emphatic and well supported in it's belief that a manager's ability to coach his employees is paramount to his ability to achieving productivity.

Today, coaching employees is both an art and a science. For some it may come naturally, yet for others training and development are necessary in an effort to hone the skills needed to be effective. The fine line of achieving a successful goal lies in the art of implementation. A sales force has been thought of as simply a collage of personalities with various wants, needs, and aspirations. They are a piece of the puzzle right out of the box, and it becomes the task of the manager to properly put that puzzle together, fitting all the pieces into a final picture. One can simply do this alone or make it easier by asking for help and collaborating along the way. It is quite explainable 
that this help will come from the actual pieces of the puzzle that are being put together - simply through empowering others. This empowerment, as professed throughout this paper, is achieved most significantly as a state of mind. Making an employee feel good about him/herself and his/her accomplishments helps to create that buy-in that is critical to any team oriented mentality. Sustainable business growth is done through its employees and through their productivity. Quite simply, a happy employee is a more productive employee.

Introspectively, humans always want to feel good about their contribution to any activity. It has been proven that a lack of training and leaving one to go it alone is nothing more than a receipt for failure. The employee today does not relate well to an authoritative approach to being managed. What is necessary is to create a feeling of success through mentorship that focuses on a manager's ability to teach - but in a coachable medium. The "Art" of coaching is created by letting the employee feel that it was he that put the successful plan together, while the "skill" is in the managers ability to subconsciously implement (through coaching) the principals necessary for success. As stated in this paper, employee development programs strongly influence career growth and job performance. This growth and productivity will always be enhanced and supported in how well a manager can coach. A manager that intimately knows all the fundamentals and successful nuances of a job, but possesses that unique ability to dispense and support that knowledge through coaching, will be the one that will always win the prize.

\section{REFERENCES}

1. Ahlrichs, N. (2000). Competing for talent: Key recruitment and retention strategies for becoming an employer of choice. Palo-Alto, CA: Davies-Black Publishing.

2. Allenbaugh, G., Eric, (1983). Training "coaching a management tool for a more effective work performance." Management Review, Volume 72, May, 1983.

3. Anonymous (2009, February). New firm helps leaders transform potential into performance with breakthrough coaching. Business Wire. Retrieved March 21, 2009, from ProQuest Central database. (Document ID: 1643757701).

4. Anonymous (2009, March). CA, Inc.; Sales coaching program from CA learning wins multiple industry awards. Telecommunications Business, 337. Retrieved March 21, 2009 from Research Library database. (Document ID: 1651841161).

5. $\quad$ Barker, J. (2005). Too good to ignore. Sales and Marketing Management, 157(3), 38-40.

6. Barlow, K. (2007). It takes more than a people person to manage a sales team. Health Care Strategic Management, 25(5), 15-16.

7. Bass, Bernard, M., (1990)."From Transactional to Transformational Leadership: Learning to Share, Organizational Dynamics, Volume 18, winter, 1990. And Development Journal, Volume 44, May, 1990.

8. Bates, P.K. (2007). Leading the sales force. Book Review Canadian Journal of Administrative Sciences, 24, 326-327.

9. Becker, G.S. (1993). Human capital: A theoretical and empirical analysis with special reference to education ( $3^{\text {rd }}$ ed.). Chicago: The University of Chicago Press.

10. Becker, B.E., Huselid, M.A. \& Ulrich, D. (2001). The HR scorecard: Linking people, strategy, and performance. Boston: Harvard Business School Press.

11. Bielous, Gary, A., (1994)."Effective Coaching: Improving Managerial Performance," Supervision, Volume 55, July, 1994.

12. Birchall, D.W. \& Tovstiga, G. (2001). Assessing the firm's strategic knowledge portfolio: A framework \& methodology. International Journal of Technology Management, 24(4), 419-434.

13. Bowles, S.V., \& Picano, J.J. (2006). Dimensions of coaching related to productivity and quality of life. Consulting Psychology Journal: Practice and Research, 58(4), 232-239.

14. Brechner, Robert, (1991)."Guidelines For The New Manager," Dryden Press, 1991.

15. Buchanan, L. (2009). Training the young guns. Inc., 31(1), 91-92.

16. Burns, James (1978). "Leadership," Harpers 1978.

17. Burpett, W.J. \& Bigoness, W. (1997). Leadership and innovation among teams-the impact of empowerment. Small Group Research, 3, 414-423.

18. Capozzoli, Thomas, (1993). "Developing Productive Employees," Supervision, Volume 54, October, 1993. 
19. Cherry, P. (2007). How to motivate your sales team to achieve next-level selling. The American Salesman, 52(11), 8-11.

20. Coutu, D., \& Kauffman, C. (2009). What can coaches do for you? Harvard Business Review, 87(1), 9197.

21. Drucker, Peter, F., (1989). "Managing the Post Business Society," Fortune July 1989.

22. Ducharme, M.J. (2004). The cognitive-behavioral approach to executive coaching. Consulting Psychology Journal: Practice and Research, 56(4), 214-224.

23. Evered, Roger, D., (1989). "Coaching and the Art of Management," Organizational Dynamics, Volume 18 , autumn, 1989.

24. Evinson, R. (2005). Managing an all-star sales team. The American Salesman, 50(10), 21-26.

25. Feltz, D.L., Chase, M. A., Moritz, S.E., \& Sullivan, P.J. (1999). A conceptual model of coaching efficacy: Preliminary investigation and instrument development. Journal of Educational Psychology, 91(4), 765-776.

26. Fernandez, S. (2008). Examining the effects of leadership behavior on employee perceptions of performance and job satisfaction. Public Performance \& Management Review, 32(2), 175.

27. Filipczak, Bob, and Picard, Michael, (1993). "Seize the Coachable Moment," Training Journal, Volume 30, February, 1993.

28. Forray, Jean, Mannhelmer, (1995). "A Good Relationship With The Boss Pays Off," Academy of Management Executive, Volume 9, Number 7, January, 1995.

29. Franco, John, (1985). "Why Coaching Is Key," $S \& M M$, Volume 134, February, 1985.

30. Frankel, Lois, P., and Otazo, Karen, L., (1992). "Employee Coaching: The Way To Gain Commitment," Employment Relations Today, Volume 19, autumn, 1992.

31. Gebhart, F. (2006). Managing right for the $21^{\text {st }}$ century. Sales and Marketing Management, 158(4), 3841.

32. Gray, A. (2008). Salesmanship: A whole new ballgame. Picture Business, 5(11), 20-21.

33. Haimann, T., Scott, W.G., \& Connor, P.E. (1985). Management, $5^{\text {th }}$ edition. Boston: Houghton Mifflin Company.

34. Hall, D.T., Otazo, K.L., \& Hollenbeck, G.P. (1999). Behind closed doors: What really happens in executive coaching. Organizational Dynamics, 27, 39-53.

35. Hart, V., Blattner, J., \& Leipsic, S. (2001). Coaching versus therapy: A perspective. Consulting Psychology Journal: Practice and Research, 53(4), 229-237.

36. Hendrickson, R. (1987). The Henry Holt encyclopedia of word and phrase origins. New York: Henry Holt.

37. Huczynski, Andrzej, (1989)."Training Designs for Organizational Change," Management Decisions, Volume 27, July, 1989.

38. Huff, A., Floyed, S., Sherman, H., Terjesen, S., (2009). "Strategic Management: Logic and Action," John Wiley \& Sons, New Jersey: pp173-74.

39. Kahle, D. (2008). Why good salespeople often turn into mediocre sales managers. The American Salesman, 53(5), 10-12.

40. Kanter, R.M. (1983). The change masters: Innovation \& Entrepreneurship in the American Corporation. New York: Simon \& Schuster.

41. Kaplan, R.S., \& Norton, D. P. (1992, January-February). The balanced scorecard - measures that drive performance. Harvard Business Review, 71-79.

42. Keough, J. (2007). Motivate your sales force. Industrial Distribution, 96(1), 25-29.

43. Kiechel, Walter, (1991). "The Boss as Coach," Fortune, Volume 124, Number 4, November, 1991.

44. Knippen, Jay, T., and Green, Thad, B., (1990). "Coaching Effective Managers Use Basic Coaching Techniques," Journal of Management Accounting, Volume 71, May, 1990.

45. Kombarakaran, F.A., Yang, J.A., Baker, M.N., \& Fernandes, P.B. (2008). Executive coaching: It Works. Consulting Psychology Journal: Practice and Research, 60(1), 78-90.

46. Kornik, J. (2007). Motivation makeover. Sales and Marketing Management, 159(2), 31-33.

47. Kreitner, R. \& Kinicki, A. (2008). Organizational Behavior, $8^{\text {th }}$ ed. New York: McGraw Hill Irwin.

48. Kuster, I. \& Canales, P. (2008). Some determinants of sales force effectiveness. Team Performance Management, 14(7/8), 296-326. 
49. Lancaster, Hal, (1995). "Managers Beware: You're Not Ready For Tomorrow's Jobs," The Wall Street Journal, January 24, 1995.

50. Limerick, D. and Cunnington, B., (1989). "Management Development: A Look at the Future," Management Decisions, Volume 27, January, 1989.

51. Lucas, Robert, W., "Effective Feedback Skills for Trainers and Coaches," Human Resource Focus Volume 71, July, 1994.

52. Lukaszewski, James, E., (1988). "Behind the Throne: How to Coach and Counsel Executives," Training and Development Journal, Volume 42, October, 1988.

53. Machin, S. \& Vognoles, A. (2004). What's the good of education? Princeton, NJ: Princeton University Press.

54. Marshal, E.M. (1995). Transforming the way we work: The power of the collaborative workplace. New York: AMACOM.

55. Martin, C. (2001). The life coaching handbook: Everything you need to be an effective life coach. Connecticut: Crown House Publishing Company LLC.

56. Mathews, P. (2004, July). Coaching for sales people: Improving the interaction between sales managers and sales people. Training Journal, 46-48.

57. McCauley, R. (2007). Building a successful mentoring program. The Journal for Quality and Participation, 30(2), 17-19.

58. Miller, K.G. (1927). Review of the psychology of coaching. Psychological Bulletin, 24(10, 608-609.

59. Olivero, G., Bane, D., \& Kopelman, R.E. (1997). Executive coaching as a transfer of training tool: Effects on productivity in a public agency. Public Personnel Management, 26, 461-470.

60. Orem, S.L., Binkert, J., \& Clancy, A.L. (2007). Appreciative Coaching. San Francisco, CA: Josey Bass

61. Peterson, D.B., \& Millier, J. (2005). The alchemy of coaching: "You're good Jennifer, but you could be really good" Consulting Psychology Journal, 57(1), 14-40.

62. Pfeffer, Jeffrey, (1995)."Producing Sustainable Competitive Advantage through the Affective Management of PeoDle." The Academy of Management Executive, Volume IX, Number 1, 1995.

63. Rao, T.V. \& Rothwell, W.J. (2000). Using the HRD audit to build convergence between HRM and OD. In W.J. Rothwell \& R.Sullivan (eds), Practicing organizational development: A guide for consultants ( $\left.2^{\text {nd }} e d.\right)$, pp 106-134, San Francisco, CA: Pfieffer. Report: Sales Organizations' Ability to Weather Current Economic Storm Depends on Four 'People Priorities'. PR Newswire. New York: November 5, 2008. Retrieved March 13, 2009, from http://proquest.umi.com/pqdweb?did=1590462811\&sid=8\&Fmt=3\&clientld=13492\&RQT $=30$ 9\&VName=PQD

64. Rich, G. (1997). The sales manager as a role model: Effects on trust, job satisfaction, and performance of salespeople. Academy of Marketing Science Journal, 25(4), 319-328.

65. Rigby, R. (2008). Road warriors. Management Today, 44-47.

66. Sanchez, D. (1998). Four tips for better coaching. Sales and Marketing Management, 150(11), 20.

67. Scholten, D.M. (2003). Be your own life coach. New York, New York: Penguin Books.

68. Shore, Lynn McFarlane, and Bloom, Arvid, J., (1986). "Developing Employees through Coaching," Personnel Management, Volume 63, August, 1986.

69. Shore, Lynn, McFarlane, and Bloom, Arvid, J., (1986). "Developing Employees through Coaching and Career Management," Personnel Journal, Volume 63, August, 1986.

70. Stern, L.R. (2004) Executive coaching: A working definition. Consulting Psychology Journal: Practice and Research, 56(3), 154-162.

71. Stone, F. (1999). Coaching, counseling and mentoring. New York: AMACOM.

72. Stoner, J.A.F., \&Wankel, C. (1986). Management, $3^{\text {rd }}$ edition. Englewood Cliffs, New Jersey: PrenticeHall.

73. Sweetland, S.R. (1996). Human capital theory: Foundations of a field of inquiry. Review of Educational Research, 66(3), 341-359.

74. Szilagyi, A.D. (1984). Management and performance, $2^{\text {nd }}$ edition. United States: Scott, Foresman and Company.

75. Thacher, C. \& Handscombe, B. (2003). Innovation, competitive position, and industry attractiveness: A tool to assist SMEs. Creativity and Innovation Management, 12(4), 230-239. 
76. Tobias, L.L. (1996). Coaching executives. Consulting Psychology Journal: Practice and Research, 48(2), 87-95.

77. Tovstiga, G. \& Tulugurova, E. (2007). Intellectual capital practices and performance in Russian enterprises. Journal of Intellectual Capital, 8(4), 695-707.

78. Tracy, B. (2008). Simple behaviors that create a top sales team. Sales and Marketing Management, 160(2), 6.

79. Wasylyshyn, K.M., Gronsky, B., \& Haas, J.W. (2006). Tigers, Stripes, and Behavior Change: Survey results of a commissioned coaching program. Consulting Psychology Journal: Practice and Research, 58(2), 65-81.

80. West, M.A. \& Anderson, N.R. (1996). The Innovation In Top Management Teams; Journal of Applied Psychology, 6, 680-693.

81. Whitworth, L. Kimsey-House, H., \& Sandahl, P. (1998). Co-active coaching; New skills for coaching people toward success in work and life. California, Davies-Black Publishing.

82. Wickman, L.E. (2008). Developing Better Sales Managers; Executive Briefings, Chief Learning Officer, Retrieved, June 18, 2009, from http://www.clomedia.com/executivebriefings/2008/December/2465/index.php

83. Wiesendanger, Betsy, (1995). "Business Psychology," Journal of Business Strategy, Volume 16, Number 1, January-February) 1995.

84. Williams, C. (2008). Management, $5^{\text {th }}$ edition. Ohio, Cengage Learning.

85. Zula, K.J. \& Chermack, T.J. (2007). Human capital planning: A review of the literature and implications for human resource development. Human Resource Development Review, 6(3), 245-262. 